\title{
Properties of Tetragenococcus halophilus Strains Isolated from Myeolchi (anchovy)-jeotgal
}

\author{
Jeong A Kim', Zhuang Yao', Venkatesh Perumal ${ }^{1}$, Hyun-Jin Kim ${ }^{1,2}$, and Jeong Hwan Kim ${ }^{1,2 *}$ \\ ${ }^{1}$ Division of Applied Life Science (BK21 plus), Graduate School, ${ }^{2}$ Institute of Agriculture and Life Science, Gyeongsang National University, \\ Jinju 52828, Republic of Korea
}

Received: April 26, 2018 / Revised: July 14, 2018/ Accepted: August 1, 2018

\begin{abstract}
Halophilic lactic acid bacteria (LAB) were isolated from myeolchi-jeotgal (23\% $\mathrm{NaCl}$, w/v) fermented in jangdok (Korean earthenware) located outside a house. They were identified as Tetragenococcus halophilus by $16 \mathrm{~S}$ rRNA and $\operatorname{rec} A$ gene sequencing. Four $T$. halophilus isolates showing high protease activities were selected for further studies. Four strains grew well, reaching $\mathrm{OD}_{600}$ values of $0.75-0.92$ at $18 \% \mathrm{NaCl}$ content (w/v) and $0.28-0.44$ at $23 \%$ salt. They showed rapid growth, attaining $\mathrm{OD}_{600}$ values of $1.1-1.2$ at $20-30^{\circ} \mathrm{C}$, but did not grow at $4{ }^{\circ} \mathrm{C}$. At $15^{\circ} \mathrm{C}$, the highest $\mathrm{OD}_{600}$ values, which exceeded 0.6 , were observed at 20 days, and were higher than those of cultures at $37{ }^{\circ} \mathrm{C}$ and $42^{\circ} \mathrm{C}$ (approximately 0.5 ). Four isolates grew best in broth where the initial $\mathrm{pH}$ was adjusted to 8 and did not grow at $\mathrm{pH} \leq 4$. T. halophilus BS2-36 showed the highest survival ratio of $18.7 \%$ after 2 hours of exposure at $\mathrm{pH}$ 3. BS2-36 showed the highest survival ratio (1.29\%) in presence of $0.3 \%$ bile salts. T. halophilus BS2-36 seems a promising candidate as a starter for jeotgal and other fermented foods with high salinities.
\end{abstract}

Keywords: Tetragenococcus halophilus, jeotgal, starter, fermented foods

\section{Introduction}

Myeolchi (anchovy) jeotgal, a Korean traditional salted-fermented food, is made by adding salt (20-30\%, $\mathrm{w} / \mathrm{w})$ to myeolchi and storing at room temperature for several months. Myeolchi jeotgal is mostly consumed as side dishes, but also used as a seasoning for Kimchi. Myeolchi jeotgal is the most popular jeotgal in Korea, but microbiota of myeolchi jeotgal has not been studied at detail.

Tetragenococcus strains are halophilic lactic acid bacteria (LAB) which have been isolated from various fermented foods with high salinities such as doenjang [1, $2]$, fish sauce [3, 4], jeotgal [5, 6], and soy sauce [7, 8]. Tetragenococcus strains were also isolated from kimchi

\section{*Corresponding author}

Tel: +82-55-772-1904, Fax: +82-55-772-1909

E-mail: jeonghkm@gnu.ac.kr

(c) 2018, The Korean Society for Microbiology and Biotechnology
[9] and fermented sausage [10]. Tetragenococcus strains can grow in the presence of $\mathrm{NaCl}$ up to around $20 \%$ $(\mathrm{w} / \mathrm{w})$ and grow fast at $20-30^{\circ} \mathrm{C}$. But they grow slowly at $37^{\circ} \mathrm{C}$ and above. Currently, 5 species are registered and they are T. halophilus, T. muriaticus, T. koreensis, T. soliatarius, and T. osmophilus [11].

Because of their high salt tolerance and the status as a member of LAB, Tetragenococcus strains have been tested for their potentials as possible starters for jeotgal for accelerating fermentation and improving flavor of products [12]. Recently, T. halophilus was tested as a starter for soy sauce fermentation and the organism was believed to contribute to the development of flavor of soy sauce [13]. But so far few studies have been done and the exact roles of Tetragenococcus strains and their effects on the quality of foods are largely unknown. More studies are required before Tetragenococcus strains are actively used as starters for various fermented foods. In addition to their positive effects, safety issues also 
should be investigated at detail [14]. In this work, properties of $4 T$. halophilus strains isolated from myeolchijeotgal were investigated.

\section{Materials and Methods}

\section{Isolation and identification of Tetragenococcus strains from myeolchi-jeotgal}

Myeolchi-jeotgals were prepared with 3 different types of salts, pure salt (PS), solar salt (SS), and bamboo salt (BS). The final salt concentration was $23 \%$ in terms of $\mathrm{NaCl}$ content $(\mathrm{w} / \mathrm{w})$. Jeotgals were fermented in jangdok, Korean traditional earthenware used for preparation of fermented foods such as ganjang (soy sauce) and doenjang (soy paste). Aliquots of myeolchi-jeotgal were taken out at 4 week and 12 week of fermentation, mixed with peptone water $(0.1 \%, \mathrm{w} / \mathrm{v})$, and homogenized by using a stomacher (stomacher ${ }^{\circledR} 80$, Seward, USA). Homogenates were serially diluted with peptone water, and diluents were spread on deMan-Rogosa-Sharpe agar (MRS, Acumedia, USA) plates (cyclohexamide, $50 \mu \mathrm{g} / \mathrm{ml}$ ). The plates were incubated for 7 days at $30^{\circ} \mathrm{C}$. Catalase test was done for colonies on MRS plates by pouring hydrogen peroxide solution (3\%). Catalase negative colonies were selected and preliminary identification was done such as Gram staining. Colonies were spotted onto MRS plates with skim milk (Acumedia, USA, 1\%, w/v) to check their proteolytic activities.

For further identification, molecular biological methods were used. 16S rRNA genes of isolates were amplified by PCR. Taq DNA polymerase was used together with primer pairs: 27F (5'AGAGTT TGATCMTGGCTCAG-3') and 1492R (5'-GGYTACCTTGTTACGACTT-3'). Part of recA genes were amplified by using following primer pairs: TrecAF (5'-GATCAACRRATTTCAACTAT-3') and TrecAR (5'-CCWACTTGTGAAATACCTTC3'). A MJ mini personal thermal cycler (BioRad, USA) was used. Initial denaturation was done at $94^{\circ} \mathrm{C}$ for 4 min followed by 30 cycles of $94^{\circ} \mathrm{C} 1 \mathrm{~min}, 45^{\circ} \mathrm{C} 45 \mathrm{~s}$ and $51^{\circ} \mathrm{C} 45 \mathrm{~s}$, and $72^{\circ} \mathrm{C} 2 \mathrm{~min}$. The final extension was done at $72^{\circ} \mathrm{C} 4 \mathrm{~min}$. Sequences were determined at Cosmogenetech (Seoul, Korea), and analyzed by BLAST (NCBI, Bethesda, USA).

\section{Salt tolerance of $T$. halophilus isolates}

Isolates were inoculated into MRS broth with $\mathrm{NaCl}$
$(8 \%, w / v)$, and incubated for 3 days at $30^{\circ} \mathrm{C}$. Isolates showing good growth were selected, and inoculated into fresh MRS broth $(3 \%, \mathrm{v} / \mathrm{v})$ with $\mathrm{NaCl}(10-25 \%, \mathrm{w} / \mathrm{v})$. Absorbances at $600 \mathrm{~nm}\left(\mathrm{OD}_{600}\right)$ of cultures were measured after 15 days at $25{ }^{\circ} \mathrm{C}$. Isolates showing significant salt tolerance were tested for their proteolytic activities.

\section{Proteolytic activities of T. halophilus isolates}

T. halophilus isolates were grown in MRS broth containing $\mathrm{NaCl}(8 \%, \mathrm{w} / \mathrm{v})$ and skim milk (Acumedia, USA $1 \%$, w/v) for $72 \mathrm{~h}$ at $30^{\circ} \mathrm{C}$. B. subtilis HK176 actively secretes proteases into culture medium, and used as a positive control [15]. B. subtilis 168, a lab strain with low protease activity, was used as a negative control [16]. $B$. subtilis HK176 and 168 strains were grown in LB broth containing skim milk (Acumedia, USA 1\%, w/v) for $72 \mathrm{~h}$ at $37^{\circ} \mathrm{C}$ with aeration. Culture supernatant was obtained after centrifugation at $12,000 \times \mathrm{g}$ for $10 \mathrm{~min}$. One hundred $\mu \mathrm{l}$ of supernatant was mixed with $1 \mathrm{ml}$ of casein (Junsei, Japan) solution (1\%, w/v) and $20 \mu \mathrm{l}$ of $\mathrm{CaCl}_{2}$ $(10 \mathrm{mM})$. One gram of casein was dissolved in either $100 \mathrm{ml}$ of $0.4 \mathrm{M}$ lactic acid buffer ( $\mathrm{pH} 3.0$, for acid protease activity measurement), $0.5 \mathrm{M}$ sodium phosphate buffer ( $\mathrm{pH}$ 6.0, for neutral protease activity measurement), or $0.2 \mathrm{M}$ boric acid-borate buffer $(\mathrm{pH} 9.0$, for alkaline protease activity measurement). Mixtures were incubated for $20 \mathrm{~min}$ at $37^{\circ} \mathrm{C}$, then $2 \mathrm{ml}$ of $5 \%$ TCA solution was added, and stood for $15 \mathrm{~min}$ at room temp (RT). Samples were centrifuged at $7,000 \times g$ for $15 \mathrm{~min}$. One $\mathrm{ml}$ of supernatant was mixed with $2 \mathrm{ml}$ of $0.5 \mathrm{M} \mathrm{NaOH}$ and $100 \mu \mathrm{l}$ of Folin-Ciocalteu reagent. The absorbance of each sample was measured at $660 \mathrm{~nm}$ after $10 \mathrm{~min}$ at RT. A standard curve was prepared using tyrosine at different concentrations. One unit of enzyme activity was expressed as the amount of enzyme which released $1 \mu \mathrm{mol}$ of tyrosine per min.

\section{Growth of T. halophilus isolates at different temperature}

T. halophilus isolates were first grown in tryptic soy broth (TSB, BD Difco, USA) with $5 \% \mathrm{NaCl}$ for $48 \mathrm{~h}$ at $30^{\circ} \mathrm{C}$, and the cultures were used to inoculate $(3 \%, \mathrm{v} / \mathrm{v})$ fresh MRS broth with $10 \% \mathrm{NaCl}(\mathrm{w} / \mathrm{v})$. The cultures were cultivated at different temperature $(4,15,20,30$, $37,42^{\circ} \mathrm{C}$ ) for 60 days. The growth was monitored by measuring the $\mathrm{OD}_{600}$ values at 5 days intervals. At 35 days and 60 days, viable cells of cultures grown at $15^{\circ} \mathrm{C}$ were 
measured by plate counting method using TSB agar with $5 \% \mathrm{NaCl}(\mathrm{w} / \mathrm{v})$.

\section{Growth of T. halophilus isolates in MRS broth with differ- ent initial pH}

T. halophilus strains were grown for $48 \mathrm{~h}$ in TSB (5\% $\mathrm{NaCl})$ at $30^{\circ} \mathrm{C}$, and then cultures were inoculated into fresh TSB broth with $5 \% \mathrm{NaCl}$ where the initial $\mathrm{pH}$ was adjusted to $\mathrm{pH} 2-10$ using $1 \mathrm{~N} \mathrm{HCl}$ and $\mathrm{NaOH}$. Inoculated cultures were incubated for $120 \mathrm{~h}$ at $30^{\circ} \mathrm{C}$, and the $\mathrm{OD}_{600}$ values were measured at $24 \mathrm{~h}$ intervals.

\section{Viability of T. halophilus isolates under acidic pH and bile salts challenges}

T. halophilus isolates were grown in TSB $(5 \% \mathrm{NaCl}$, $\mathrm{w} / \mathrm{v}$ ) for $48 \mathrm{~h}$ at $30^{\circ} \mathrm{C}$. One $\mathrm{ml}$ of culture was centrifuged at 13,000 $\times \mathrm{g}$ for $10 \mathrm{~min}$, and the cell pellet was obtained. After washing with cold, sterile water, cells were resuspended in $1 \mathrm{ml}$ of distilled water whose $\mathrm{pH}$ was adjusted to 2 , 3, or 6.5 (control) by $1 \mathrm{~N} \mathrm{HCl}$ or $1 \mathrm{~N} \mathrm{NaOH}$. After $2 \mathrm{~h}$ at $30^{\circ} \mathrm{C}$, viable cells were counted by plate count method using TSB agar with $5 \% \mathrm{NaCl}$. Plates were incubated for $96 \mathrm{~h}$ at $30^{\circ} \mathrm{C}$. Cells were also resuspended in $0.3 \%$ bile salts (B8756, Sigma-Aldrich, USA) solution and stood for $2 \mathrm{~h}$ at $30^{\circ} \mathrm{C}$, and then viable cells were counted. Survival ratios (SR, \%) were calculated by dividing the viable cell numbers under stress by the control cell number ( $\mathrm{pH}$ 6.5).

\section{Results and Discussion}

\section{Isolation and identification of tetragenococci}

Several isolates showing significant salt tolerance and protease activities were obtained, and 4 strains were finally selected for further studies. They were gram + cocci. For identification, 16S rRNA genes were amplified and sequenced: BS1-37 (1,180 nucleotides), BS2-36 (1,368 nucleotides), PS1-25 (1,376 nucleotides), and SS32 (1,372 nucleotides). BLAST analyses showed that the sequences showed 99-100\% identities with those from $T$. halophilus strains. In addition, partial recA gene sequences (536-587 nucleotides) were determined. BLAST analyses showed that the sequences had 99100\% identities with those from T. halophilus strains (results not shown). From these results, 4 isolates were identified as T. halophilus strains. Genbank numbers of

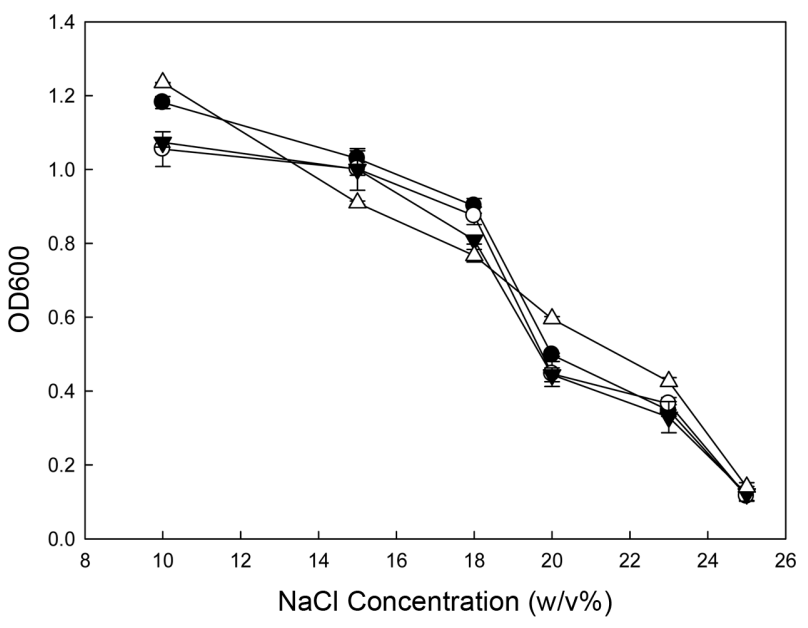

Fig. 1. Growth of T. halophilus strains in MRS broth with different $\mathrm{NaCl}$ contents. T. halophilus isolates were inoculated into MRS broth with $\mathrm{NaCl}(10,15,18,20,23$, and 25\%, w/v) and grown for 15 days at $25^{\circ} \mathrm{C}$. - - - T. halophilus BS1-37;- $\bigcirc-$ T. halophilus BS2-36; - - - T. halophilus PS1-25; - $\triangle$ - T. halophilus SS3-2.

16S rRNA genes from BS1-37, BS2-36, PS1-25, and SS32 are MG905357, MG905358, MG905359, and MG905360, respectively. Genbank numbers of $r e c A$ genes from BS137, BS2-36, PS1-25, and SS3-2 are MG912952, MG912953, MG912954, MG912955, respectively.

\section{Salt tolerance of T. halophilus isolates}

Salt tolerance of isolates were examined during growth in MRS broth with $\mathrm{NaCl}(10-25 \%$, w/v). All isolates grew well up to $18 \%$ salt, showing the $\mathrm{OD}_{600}$ values of $0.75-0.92$ at $18 \%$ salt. At $20 \%$ salt, SS3-2 grew better than other isolates, and absorbance at $600 \mathrm{~nm}\left(\mathrm{OD}_{600}\right)$ was $0.60 \pm 0.01$ at 15 days (Fig. 1). BS1-37 was the second, showing $\mathrm{OD}_{600}$ of $0.50 \pm 0.01$. BS2-36 and PS1-25 showed similar values $(0.44-0.45)$. All strains showed some growth activity $(0.28-0.44)$ at $23 \% \mathrm{NaCl}$ concentration but did not grow at $25 \%$ salt. Most LAB can't grow at high salt concentration, and the results confirmed that $4 T$. halophilus strains are halophilic, and can be used as a starter for jeotgals.

\section{Proteolytic activities of $T$. halophilus isolates}

For acid protease activity, SS3-2 showed the highest value, $2.30 \pm 0.02 \mathrm{U} / \mathrm{ml}$ (Fig. 2). Other strains showed slightly lower values (2.20-2.29 U/ml). but the activities were still higher than that of Bacillus subtilis HK176 $(1.76 \pm 0.07 \mathrm{U} / \mathrm{ml})$. B. subtilis 168 , a negative control, 


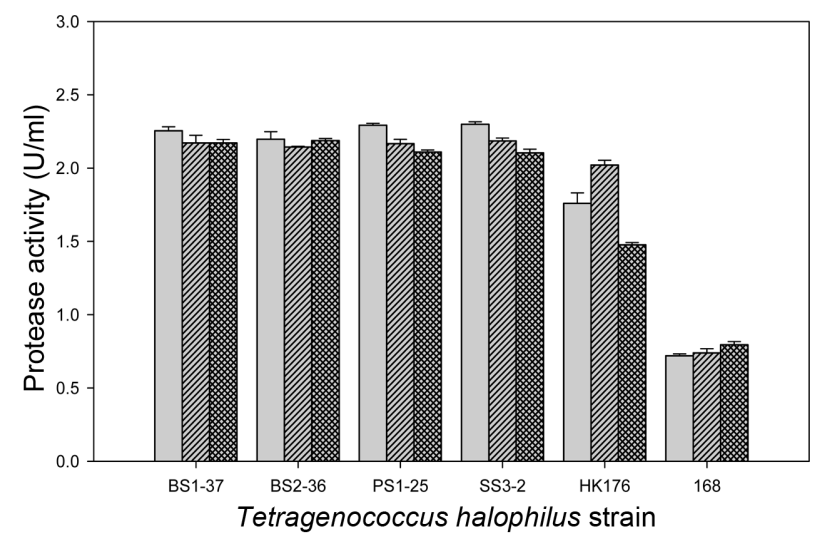

Fig. 2. Proteolytic activities of $T$. halophilus strains. acid protease activity (pH 3.0); $2 Z Z Z$, neutral protease activity (pH 6.0); resents Bacillus subtilis HK176 (a positive control) and 168 represents $B$. subtilis 168 (a negative control).

showed $0.72 \pm 0.01 \mathrm{U} / \mathrm{ml}$. Similar results were observed for neutral protease activities. SS3-2 showed the highest value $(2.19 \pm 0.02 \mathrm{U} / \mathrm{ml})$ and other strains showed slightly lower values. All strains showed higher activities than B. subtilis HK176. For alkaline protease activity, BS2-36 showed the highest value $(2.19 \pm 0.01 \mathrm{U} / \mathrm{ml})$, and BS1-37 was the second $(2.17 \pm 0.02 \mathrm{U} / \mathrm{ml})$. Other 2 strains showed slightly lower values $(2.10-2.11 \mathrm{U} / \mathrm{ml})$, but the values were significantly higher than those of $B$. subtilis HK176 $(1.48 \pm 0.02 \mathrm{U} / \mathrm{ml})$ and B. subtilis 168 $(0.79 \pm 0.02 \mathrm{U} / \mathrm{ml})$.

\section{Growth of T. halophilus isolates at different temperature}

T. halophilus isolates grew well at $20^{\circ} \mathrm{C}$ and $30^{\circ} \mathrm{C}$ (Fig. 3). Growth at $30^{\circ} \mathrm{C}$ was slightly better than growth at $20^{\circ} \mathrm{C}$ within the first 10 days. But no significant differences were observed after 10 days. All isolates grew quickly within the first 5-10 days, and showed the highest $\mathrm{OD}_{600}$ values (ca. 1.2). After 10 days, the values decreased gradually, reaching to $1.0-1.1$ at 60 days. All isolates did not grow at $4{ }^{\circ} \mathrm{C}$. At $37^{\circ} \mathrm{C}$ and $42^{\circ} \mathrm{C}$, isolates grew quickly within the first 10 days, but the highest $\mathrm{OD}_{600}$ values were less than 0.6 , and similar values were
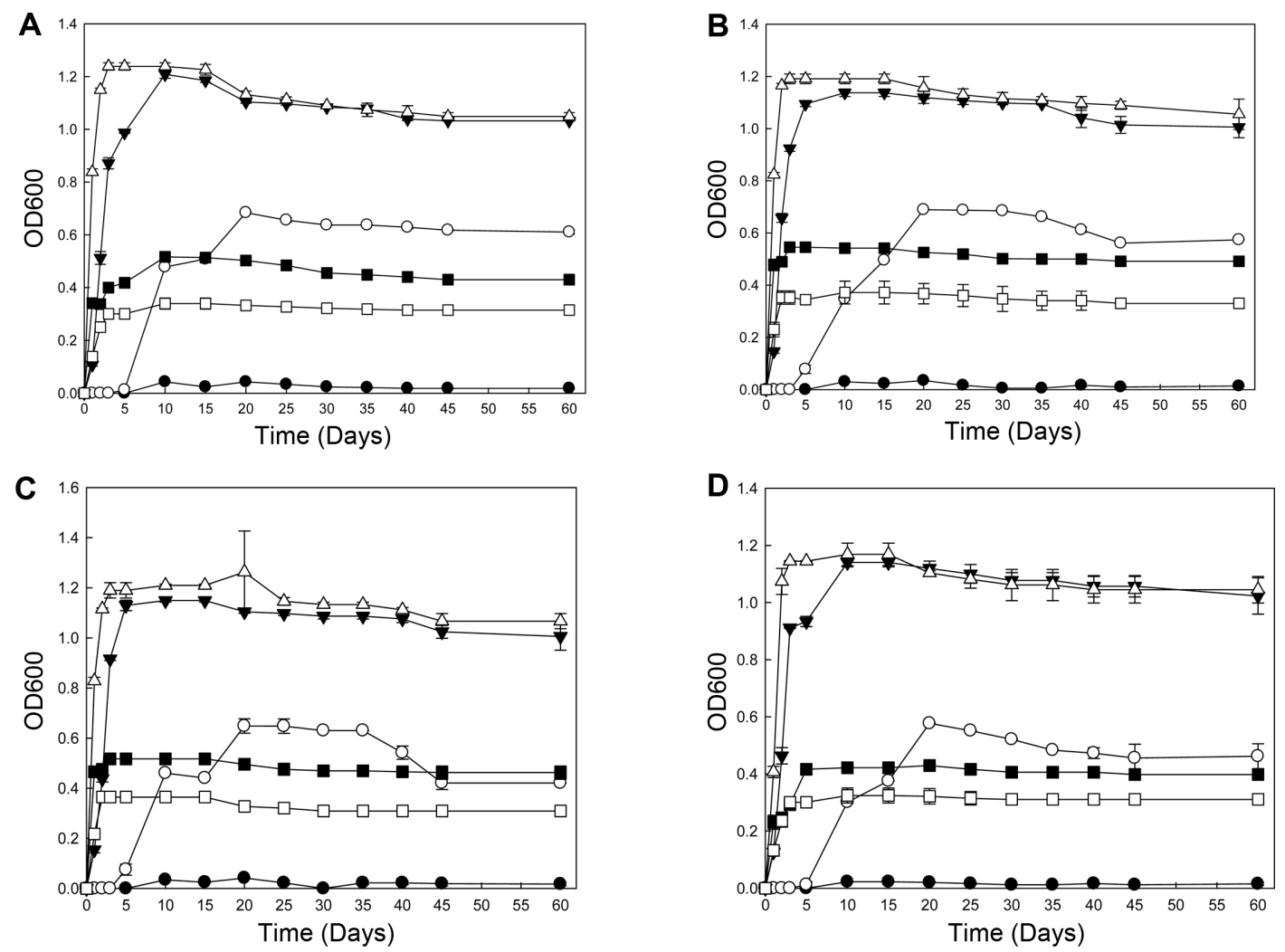

Fig. 3. Growth of $T$. halophilus strains at different temperature. $T$. halophilus isolates were inoculated into $\mathrm{MRS}$ broth with $\mathrm{NaCl}$ $(10 \%, w / v)$ and grown for 60 days at different temp. $-\mathbf{-}-4^{\circ} \mathrm{C} ;-\bigcirc-15^{\circ} \mathrm{C} ;-\nabla-20^{\circ} \mathrm{C} ;-\triangle-30^{\circ} \mathrm{C} ;-\mathbf{\square}-37^{\circ} \mathrm{C} ;-\square-42^{\circ} \mathrm{C}$. (A) BS1-37, (B) BS236, (C) PS1-25, (D) SS3-2. 
Table 1. Viable cells of T. halophilus isolates grown for $\mathbf{3 5}$ and 60 days at $15{ }^{\circ} \mathrm{C}$.

\begin{tabular}{ccc}
\hline \multirow{2}{*}{ Strain } & 35 days & 60 days \\
\cline { 2 - 3 } & \multicolumn{2}{c}{ CFU/ml } \\
\hline BS1-37 & $4.1 \times 10^{7}$ & $4.0 \times 10^{7}$ \\
BS2-36 & $6.5 \times 10^{7}$ & $3.5 \times 10^{7}$ \\
SS3-2 & $8.4 \times 10^{7}$ & $8.0 \times 10^{7}$ \\
PS1-25 & $6.0 \times 10^{7}$ & $5.7 \times 10^{7}$ \\
\hline
\end{tabular}

Tryptic soy agar plates with $5 \% \mathrm{NaCl}$ were used for viable cell counting.

maintained until 60 days. At $15^{\circ} \mathrm{C}$, the highest values (0.69-0.58) were observed at 20 days, and the values decreased gradually. At 60 days, the values were in the range of $0.42-0.61$. From these results, it was concluded that the optimum temperature for T. halophilus isolates was $20-30^{\circ} \mathrm{C}$. T. halophilus strains isolated from sea water and mountain snow did not grow at $4{ }^{\circ} \mathrm{C}$ and $40^{\circ} \mathrm{C}$ [17]. Whereas some T. halophilus strains isolated from fish sauce mashes grew at $45^{\circ} \mathrm{C}$ [4]. These results indicate that variations are present among T. halophilus
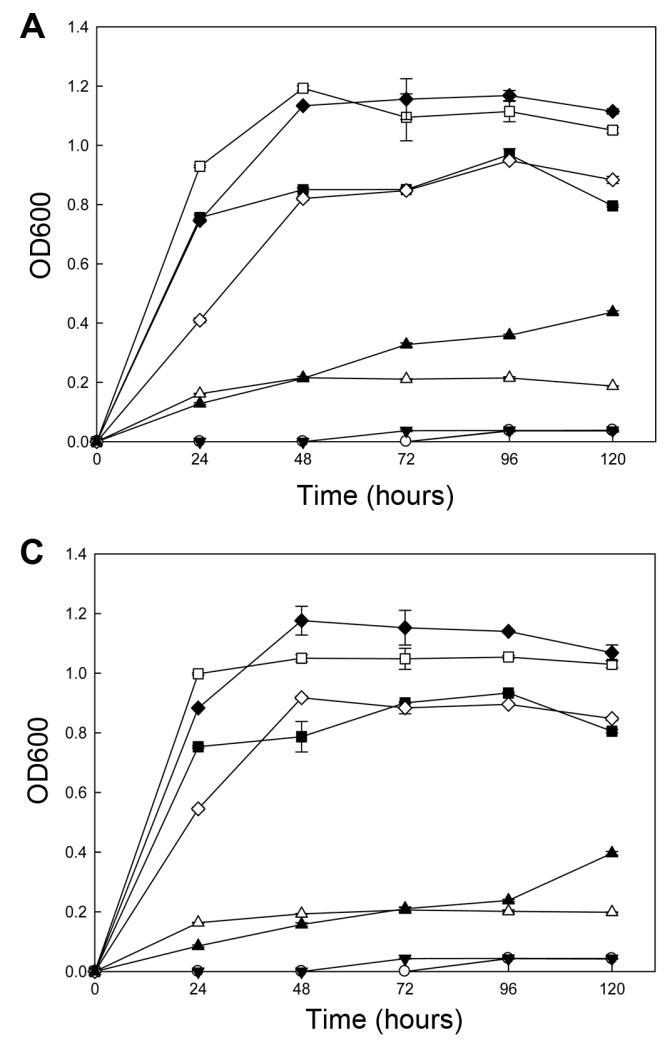

strains. Viable cells of cultures grown at $15^{\circ} \mathrm{C}$ were counted at 35 and 60 days and the results were similar among isolates (Table 1). 4.1-8.4 × 10 $\mathrm{CFU} / \mathrm{ml}$ were maintained at 35 days and slightly reduced counts, 3.5$8.0 \times 10^{7}$, were observed at 60 days. $\mathrm{OD}_{600}$ values of cultures were $0.48-0.66$ at 35 days and $0.42-0.61$ at 60 days.

\section{Growth of T. halophilus isolates in MRS broth with differ- ent initial pH}

All isolates showed a same pattern of $\mathrm{pH}$ changes when grown in MRS broth $(\mathrm{NaCl}, 8 \%)$ for $72 \mathrm{~h}$ at $30^{\circ} \mathrm{C}$, i.e. $\mathrm{pH}$ decreased continuously, and reached to 4.6-4.8 at $72 \mathrm{~h}$ (results not shown). The $\mathrm{OD}_{600}$ values were $1.1-$ 1.2 at 72 h. T. halophilus isolates grew best in TSB with the initial $\mathrm{pH}$ of 7 and 8 , reaching to the highest $\mathrm{OD}_{600}$ values of 1.2 at $48 \mathrm{~h}$ (Fig. 4). They also grew well at the initial $\mathrm{pH}$ of 6 and 9. They grew slowly at $\mathrm{pH} 10$ except SS3-2. SS3-2 did not grow at initial $\mathrm{pH}$ of 10. SS3-2 did not grow at initial $\mathrm{pH}$ of 5 whereas other strains grew a little bit (0.18-0.2). All strains failed to grow at pH 4 and below.
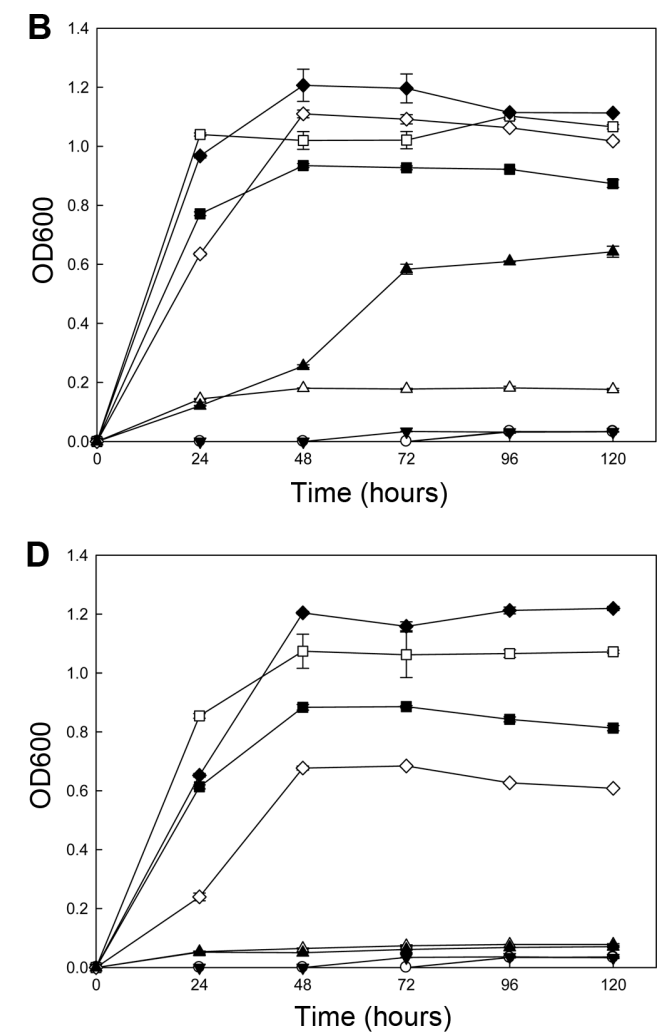

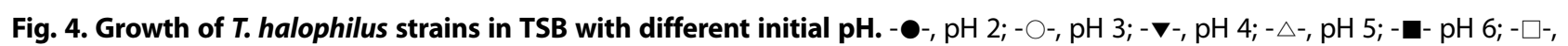
pH 7; --, pH 8; - - pH 9; - - pH 10. (A) BS1-37, (B) BS2-36, (C) PS1-25, (D) SS3-2. 
Table 2. SR of T. halophilus isolates after acid, bile salts, and combined challenges.

\begin{tabular}{|c|c|c|c|}
\hline Strain & Challenge & $\mathrm{CFU} / \mathrm{ml}$ & Survival ratio (\%) \\
\hline \multirow[t]{5}{*}{ BS1-37 } & Control (pH 6.5) & $1.7 \times 10^{8}$ & 100 \\
\hline & $\mathrm{pH} 2.0$ & 0.0 & 0.0 \\
\hline & $\mathrm{pH} 3.0$ & $3.6 \times 10^{2}$ & 0.0 \\
\hline & $0.3 \%$ bile salts (BS) & $1.8 \times 10^{6}$ & 1.1 \\
\hline & $\mathrm{pH} 3.0+0.3 \% \mathrm{BS}$ & 0.0 & 0.0 \\
\hline \multirow[t]{5}{*}{ BS2-36 } & Control (pH 6.5) & $1.6 \times 10^{8}$ & 100 \\
\hline & $\mathrm{pH} 2.0$ & $1.0 \times 10^{2}$ & 0.0 \\
\hline & $\mathrm{pH} 3.0$ & $2.9 \times 10^{7}$ & 18.7 \\
\hline & $0.3 \%$ bile salts (BS) & $2.0 \times 10^{6}$ & 1.3 \\
\hline & $\mathrm{pH} 3.0+0.3 \% \mathrm{BS}$ & $7.0 \times 10^{1}$ & 0.0 \\
\hline \multirow[t]{5}{*}{ SS3-2 } & Control (pH 6.5) & $8.2 \times 10^{7}$ & 100 \\
\hline & $\mathrm{pH} 2.0$ & 0.0 & 0.0 \\
\hline & $\mathrm{pH} 3.0$ & $1.2 \times 10^{6}$ & 1.5 \\
\hline & $0.3 \%$ bile salts (BS) & $7.9 \times 10^{5}$ & 1.0 \\
\hline & $\mathrm{pH} 3.0+0.3 \% \mathrm{BS}$ & 0.0 & 0.0 \\
\hline \multirow[t]{5}{*}{ PS1-25 } & Control (pH 6.5) & $9.8 \times 10^{7}$ & $100 \%$ \\
\hline & $\mathrm{pH} 2.0$ & 0.0 & 0.0 \\
\hline & $\mathrm{pH} 3.0$ & $7.0 \times 10^{6}$ & 7.1 \\
\hline & $0.3 \%$ bile salts (BS) & $9.2 \times 10^{5}$ & 0.9 \\
\hline & $\mathrm{pH} 3.0+0.3 \% \mathrm{BS}$ & 0.0 & 0.0 \\
\hline
\end{tabular}

\section{Viability of $T$. halophilus isolates under acidic $\mathrm{pH}$ and bile salt challenges}

All T. halophilus cells were killed after 2 hours exposure at $\mathrm{pH} 2.0$ except BS2-36. Few BS2-36 cells survived but the SR was very close to 0\% (Table 2). Most cells were killed by $2 \mathrm{~h}$ exposure at $\mathrm{pH} 3.0$, and SRs were 0 $18.7 \%$. BS2-36 showed the highest SR, 18.7\% whereas BS1-37 was the most sensitive. BS2-36 also showed the highest SR (1.29\%) against $0.3 \%$ bile salts challenge. After exposure to $\mathrm{pH} 3$ and $0.3 \%$ bile salts at the same time, few BS2-36 cells still survived whereas cells from other strains were completely killed. Compared to LAB originated from dairy environments, T. halophilus strains isolated from myeolchi-jeotgal showed lower degree of resistance against acidic $\mathrm{pH}$ and bile salts challenges [18]. Especially, resistance against $0.3 \%$ bile salts was quite lower than LAB isolated from human feces [19]. The results were not surprising considering the natural environments where Tetragenococcus strains are often isolated.

Temperature and salt content are the 2 most import- ant factors which determine the types of dominant microorganisms and the final quality of foods during food fermentation [20]. Thus understanding the growth properties of starters is the first step for establishing optimum fermentation conditions for the production of high quality fermented foods. If $T$. halophilus strains in this study are used as starters for myeolchi-jeotgal, fermentation can be carried out at low temperature and high salt conditions. Thus it seems possible to produce high quality myeolchi-jeotgal without deterioration for a long time. Four T. halophilus strains might be useful as starters for jeotgal and other fermented foods with high salinities although their safety should be confirmed before use. Among 4 isolates, T. halophilus BS2-36 seems to be most suitable as a starter since the strain possesses significant degree of resistance against low $\mathrm{pH}$ $(\mathrm{pH} 3.0)$ and $0.3 \%$ bile salts. Future studies are necessary on the production of fermented foods using T. halophilus BS2-36 as a starter.

\section{Acknowledgments}

This study was supported by grant 20130290 to the Solar Salt Research Center of Mokpo, National University, from the Ministry of Oceans and Fisheries, Korea. J. A Kim and Z. Yao were also supported by BK21 Plus program from Ministry of Education, Korea.

\section{Conflict of Interest}

The authors have no financial conflicts of interest to declare.

\section{References}

1. Jeong DW, Kim HR, Jung G, Han S, Kim CT, Lee JH. 2014. Bacterial community migration in the ripening of Doenjang, a traditional Korean fermented soybean food. J. Microbiol. Biotechnol. 24: 648660.

2. Kim TW, Lee JH, Kim SE, Park MH, Chang HC, Kim HY. 2009. Analysis of microbial communities in doenjang, a Korean fermented soybean paste, using nested PCR-denaturing gradient gel electrophoresis. Int. J. Food Microbiol. 131: 265-271.

3. Fukui Y, Yoshida M, Shozen KI, Funatsu Y, Takano T, Oikawa H, et al. 2012. Bacterial communities in fish sauce mash using culturedependent and -independent methods. J. Gen. Appl. Microbiol. 58: 273-281.

4. Udomsil N, Rodtong S, Tanasupawat S, Yongsawatdigul J. 2010. Proteinase-producing halophilic lactic acid bacteria isolated from fish sauce fermentation and their ability to produce volatile compounds. Int. J. Food Microbiol. 141: 186-194. 
5. Han Kl, Kim YH, Hwang SG, Jung EG, Patnaik BB, Han YS, et al. 2014. Bacterial community dynamics of salted and fermented shrimp based on denaturing gradient gel electrophoresis. J. Food Sci. 79: M2516-2522.

6. Kim MS, Park EJ. 2014. Bacterial communities of traditional salted and fermented seafoods from Jeju island of Korea using $16 \mathrm{~S}$ rRNA gene clone library analysis. J. Food Sci. 79: M927-934.

7. Masuda S, Yamaguchi H, Kurokawa T, Shirakami T, Tsuji RF, Nishimura I. 2008. Immunomodulatory effect of halophilic lactic acid bacterium Tetragenococcus halophilus Th221 from soy sauce moromi grown in high-salt medium. Int. J. Food Microbiol. 121: 245-252.

8. Tanaka Y, Watanabe J, Mogi Y. 2012. Monitoring of the microbial communities involved in the soy sauce manufacturing process by PCR-denaturing gradient gel electrophoresis. Food Microbiol. 31: 100-106.

9. Lee M, Kim MK, Vancanneyt M, Swings J, Kim SH, Kang MS, et al. 2005. Tetragenococcus koreensis sp. nov., a novel rhamnolipidproducing bacterium. Int. J. Syst. Evol. Microbiol. 55: 1409-1413.

10. Amadoro C, Rossi F, Piccirilli M, Colavita G. 2015. Tetragenococcus koreensis is part of the microbiota in a traditional Italian raw fermented sausage. Food Microbiol. 50: 78-82.

11. Justé $A$, Van Trappen S, Verreth C, Cleenwerck I, De Vos P, Lievens B, et al. 2012. Characterization of Tetragenococcus strains from sugar thick juice reveals a novel species, Tetragenococcus osmophilus sp. nov., and divides Tetragenococcus halophilus into two subspecies, T. halophilus subsp. halophilus subsp. nov. and T. halophilus subsp. flandriensis subsp. nov. Int. J. Syst. Evol. Microbiol. 62: 129-137.

12. Udomsil N, Rodtong S, Choi YJ, Hua Y, Yongsawatdigul J. 2011.
Use of Tetragenococcus halophilus as a starter culture for flavor improvement in fish sauce fermentation. J. Agric. Food Chem. 59: 8401-8408.

13. Harada R, Yuzuki M, Ito K, Shiga K, Bamba T, Fukusaki E. 2018. Microbe participation in aroma production during soy sauce fermentation. J. Biosci. Bioeng. 125: 688-694.

14. Jeong DW, Heo S, Lee JH. 2017. Safety assessment of Tetragenococcus halophilus isolates from doenjang, a Korean high-salt-fermented soybean paste. Food Microbiol. 62: 92-98.

15. Jeong SJ, Heo K, Park JY, Lee KW, Park JY, Joo SH, et al. 2015. Characterization of AprE176, a fibrinolytic enzyme from Bacillus subtilis HK176. J. Microbiol. Biotechnol. 25: 89-97.

16. Jeong SJ, Park JY, Lee JY, Lee KW, Cho KM, Kim GM, et al. 2015. Improvement of fibrinolytic activity of Bacillus subtilis 168 by integration of a fibrinolytic gene into the chromosome. J. Microbiol. Biotechnol. 25: 1863-1870.

17. Uchida M, Miyoshi T, Yoshida G, Niwa K, Mori M, Wakabayashi H. 2014. Isolation and characterization of halophilic lactic acid bacteria acting as a starter culture for sauce fermentation of the red alga Nori (Porphyra yezoensis). J. Appl. Microbiol. 116: 1506-1520.

18. Tham CSC, Peh KK, Bhat R, Liong MT. 2012. Probiotic properties of bifidobacteria and lactobacilli isolated from local dairy products. Ann. Microbiol. 62: 1079-1087.

19. Lee KW, Park JY, Jeong HR, Heo HJ, Han NS, Kim JH. 2012. Probiotic properties of Weissella strains isolated from human feces. Anaerobe 18: 96-102.

20. Lee ME, Jang JY, Lee JH, Park HW, Choi HJ, Kim TW. 2015. Starter cultures for kimchi fermentation. J. Microbiol. Biotechnol. 25: 559568. 